\title{
The Role of Cancer Stem Cells and MicroRNAs in Human Prostate Cancer
}

\author{
Mustafa Ozen ${ }^{1,2,3}$ and Serhat Sevli ${ }^{1}$ \\ ${ }^{1}$ Department of Medical Genetics Istanbul University Cerrahpasa Medical School, Istanbul \\ ${ }^{2}$ Bezmialem Vakif University, Istanbul \\ ${ }^{3}$ Department of Pathology \& Immunology Baylor College of Medicine, Houston, TX \\ 1,2Turkey \\ ${ }^{3}$ USA
}

\section{Introduction}

The Cancer Stem Cell (CSC) s are potentially tumorigenic cells supporting initiation, survival and spread of the tumor. Several researches have been reported that CSCs are present and active in a variety of tumors including lung, brain, and breast, prostate and ovarian cancers. Inspite of the debate between basal or luminal origin of prostate cancer, the accepted idea is that progenitor cells of both cell types give rise to the disease. The other names given to the prostate cancer originating cells are stromal-like or stem-like, tumor progenitor and tumor initiating cells. The idea of CSCs is generated by their differentiation potential and slow growing and also tumors' clonality and possessing minor amounts of stem cell like cells.

CSCs are identified by their tissue specific stem cell-like properties. The most common surface markers for isolation of prostate cancer stem cells are CD44, integrin-alpha(2) beta(1) and CD133. Other methods are Hoechst 33342 dye exclusion, and holoclone formation for showing stemness of CSCs.

True identification and characterization of CSCs is promising for development of novel treatment options by targeting specifically CSCs. Classic therapies target the fast-dividing and differentiated cancer cells. However, CSCs grow and divide slowly and are mostly resistant against most cancer therapies. After the therapy, some cells responsible from tumor relapse and metastasis remain intact.

MicroRNAs are the most popular small RNAs regulating mRNA expression. MiRNAs are transcribed from the DNA as primary-miRNA form and are cut by special nucleases and obtain hairpin precursor-miRNA structure. The adult single stranded 20-25 nucleotides miRNA in cytoplasm inhibit protein synthesis by targeting semi-complementary sequences on $3^{\prime}$-untranslated regions of mRNA. MiRNAs have specific mRNA targets and approximately $30 \%$ of transcripts are controlled by miRNAs. The alterations of miRNA expression in different tumor types and widespread deregulation in Prostate Tumors have been identified in recent years. The miRNAs are determined as potential therapeutic targets and diagnostic tumor markers from both tissue and blood, due to their specifically overexpressed or down-regulated expression in variable tumor types. miRNAs, commonly upregulated in tumor cells and inhibit tumor suppressor genes and promote cell 
proliferation in tumor cells are termed as oncogenic miRNAs or oncomirs. On the other hand, the miRNAs which are commonly down-regulated in tumor cells and inhibit tumor development are called tumor suppressor miRNAs.

Additionally, differential expression of miRNAs in Cancer Stem Cells of prostate tumors has been under investigation in recent years. Those two popular topics are seemed to provide novel information on the way of understanding the prostate cancer molecularly and providing new insights for prostate cancer diagnosis and therapy.

\section{Prostate cancer stem cells (CSCs)}

Prostate Cancer is one of the most frequent tumors among men in the developed countries. The locally advanced or metastatic types of prostate tumors mostly do not respond to current treatment options. Androgen independent prostate tumors are mostly lethal after androgen-ablation therapy and so the chemotherapy and radiotherapy resistant tumors are (Collins \& Maitland, 2006).

The epithelial cell layer of prostate tissue is divided into two layers of basal and luminal that contain three subpopulation of cells; Basal cells, neuroendocrine cells and luminal cells. These cells are distinguished by their localization, morphology and phenotypes. The basal and neuroendocrine cells are along the basement membrane of prostate and the latter secretes neuroendocrine peptides to promote epithelial viability and growth of the gland. The luminal cells stay above basal cell layer and function to secrete prostate specific molecules through luminal space. The prostatic stem cells are commonly present in these epithelial cell populations, especially in basal cell subpopulation (Lawson \& Witte, 2007; Miki \& Rhim, 2008). The molecular markers of prostatic epithelial cells are characterized to identify the origin of normal and CSCs (Lawson \& Witte, 2007). The androgen dependent luminal secretory cells express AR, prostate specific antigen, prostatic acid phosphatase, CD57, and low molecular weight cytokeratin (Miki \& Rhim, 2008). The androgen independent non-secretory basal cells do not express androgen receptor (or low levels of AR), prostate specific antigen or prostatic acid phosphatase but present CD44, p63, and high molecular weight cytokeratin. The normal stem cells among basal cells amplify to differentiate into androgen independent transit amplifying cells (TACs) and these cells further differentiate to form androgen dependent luminal cells (Miki \& Rhim, 2008; Wang \& Shen, 2011).

\subsection{The cancer stem cell theory}

The cancer stem cell theory proposed more than a century ago. However, its molecular details have been understood in recent years. In 1950s, the first reliable studies about CSCs were conducted by Ernest McCulloch and James Till in Toronto. In recent years by the development of flow cytometry and xenotransplantation techniques, researchers know more about their molecular roles and pathogenic properties. The CSCs are also called cancer progenitor cells or tumor initiating cells, meaning that they have intrinsic and/or acquired capacity to initiate tumor and these cells are resistant against current clinical treatment strategies (Masters et al., 2008).

There are epithelial somatic stem cells and progenitor cells in basal and neuroendocrine cell layers of prostate tissue. When investigators retrieve androgen from the tissue, the epithelial cells die. Arise of epithelial layer after providing the androgen back, supports the idea of 
presence of stem-like cells in prostate tissue. Additionally, prostate stem cells should be androgen-independent cells surviving without of it (Lawson \& Witte, 2007).

Early evidences about cancer provided the idea that prostate cancer is formed by a one mutated cell that the entire tumor is homogenous clone of that originating cell. Cancer stem cell theory fits the clonality part today. It is well-known that tumor consists of heterogeneous cells with different tumorigenic capacity and possibly more than one initiator cells.

There are two important ideas about CSCs and prostate cancer connection: CSCs can potentially contribute to tumor development and they cause initiation and advancement of prostate tumors themselves (Collins \& Maitland, 2006).

Both somatic stem cells and CSCs are capable of organogenesis. Somatic adult stem cells have potential to form multilineage of cells in a tissue. The CSCs are also able to repopulate tumor cells in distinct locations (Miki \& Rhim, 2008). The cancer stem cell model suggests that tumor arises from tumor-initiating, self-renewing and differentiating stem-like cell. The differentiated cancer cells lack tumorigenesis capacity (Wang \& Shen, 2011).

Prostate cancer as well as other solid tumor types comprise of heterogeneous cell types. The current cancer stem cell theory suggest that the prostate tumor contain minor amount of self-renewing cells possessing stem cell phenotypes and they are possibly responsible from proliferation, recurrence, and resistance to apoptosis of tumors (Lam \& Reiter, 2006). According to recent experimental evidences, tumors also arise from stem-cell derived progenitor cells or differentiated cells (Lam and Reiter, 2006; Miki and Rhim, 2008; Wang and Shen, 2011). Thus the tumor-initiating cells might not always mean that they have CSC properties but by the oncogenic transformations differentiated cells or progenitor cells may have in vivo tumorigenic capacity and this is compatible with clonal evolution model.

\begin{tabular}{|c|c|c|c|}
\hline \multicolumn{4}{|c|}{ Cancer Stem Cells } \\
\hline $\begin{array}{c}\text { Clinical } \\
\text { Implications }\end{array}$ & Properties & Origin & $\begin{array}{c}\text { Specific } \\
\text { Pathways }\end{array}$ \\
\hline $\begin{array}{c}\text { Current } \\
\text { treatments often } \\
\text { fail to eliminate } \\
\text { CSCs }\end{array}$ & $\begin{array}{c}\text { Aberration in mitosis } \\
\text { rate due to genomic } \\
\text { mutations }\end{array}$ & $\begin{array}{c}\text { Present in the tissue } \\
\text { where tumor arise }\end{array}$ & Sonic hedgehog \\
\hline & $\begin{array}{c}\text { Differentiation and } \\
\text { self renewal } \\
\text { capability }\end{array}$ & $\begin{array}{c}\text { Originated from stem, } \\
\text { progenitor, or } \\
\text { differentiated cells }\end{array}$ & Wnt/B-catenin \\
\hline & $\begin{array}{c}\text { Small population of } \\
\text { cells with similar } \\
\text { marker proteins }\end{array}$ & & $\begin{array}{c}\text { Notch signaling } \\
\text { system }\end{array}$ \\
\hline
\end{tabular}

Table 1. Important features of cancer stem cells. Derived from the article of (Lobo et al., 2007)

The stem cell specific pathways, Wnt/ $\beta$-catenin, Notch, and Hedgehog signaling pathways are frequently activated and implicated in self-renewal and cell fate of CSCs. The TGF $\beta$ signaling aims to keep the stem cells in quiescent state. The Epithelial growth factor receptor, EGFR, Platelet derived growth factor receptor, PDGFR, Stem cell factor, SCF, PTEN, and TP53 genes are also functioning in regulation of CSCs (Kelly \& Yin, 2008; Korkaya \& Wicha, 2007; Mimeault et al., 2007). 
Another cancer organization model is the clonal evolution of tumor. According to this model of carcinogenesis, the tumors have a distinct type of and several tumor-initiating cells; thus the tumor may consist of more than one clone of cells. The cancer stem cell and clonal evolution theories support each other when the tumor may contain different clones originated from different stem or progenitor cells as schematized in Figure 1. Thus the cancer therapy should target all these clones specifically or commonly (Wang \& Shen, 2011).

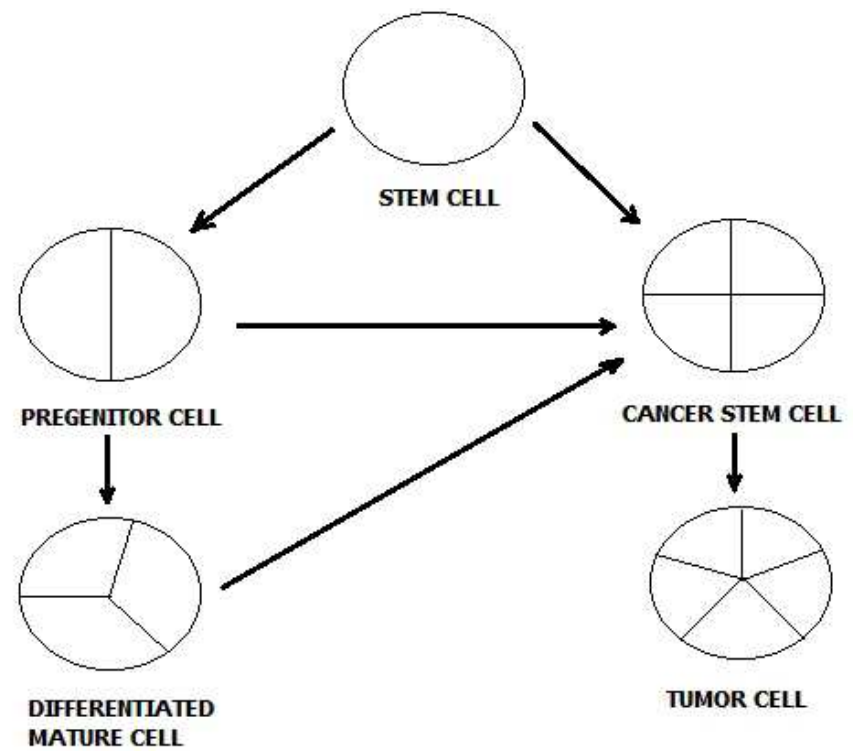

Fig. 1. Cancer stem cell formation

\subsection{Identification of prostate cancer stem cell (PCSC) s}

The cells being potentially prostate CSCs are identified generally by three experimental methods: clonal assay, separation by cell surface markers, and side population analysis. The studies show the existence of prostate CSCs using the primary prostate tumor samples, prostate cancer cell lines and animal models (Miki \& Rhim, 2008).

We can separate the CSCs in prostate tumors by specific molecular markers. The surface markers for stem cells of one tissue or tumor do not always match to another tissue or tumor.

$\mathrm{AR}$ expression is the most common phenotype. The CSCs possess high in vitro proliferation potential. The cells of primary prostate cancer that show higher proliferation capacity do not express AR (Lawson \& Witte, 2007). The normal prostate stem cells are also lack AR expression, thus both prostate CSCs and normal SCs do not need androgen for growth (Miki \& Rhim, 2008).

Commonly accepted antigen profile for prostate specific CSCs is CD44+a2 31 hiCD133+. This profile is in accordance with the normal prostate SCs (Lawson \& Witte, 2007). The cells separated only by CD44 presence have enhanced proliferative activity in vitro. The CD44+ prostate cancer cells also lack of AR and they have tumor initiating and metastasis functions. The CSCs are known with their similar stemness genes' expression. Other than CD44 and CD133, prostate cancer cells also express higher levels of OCT3, OCT4, Nanog, Sox2, CD117, $\beta$-catenin, and BMI1 (Lawson \& Witte, 2007). 
The prostate cancer cells that express high levels of a2 31 integrin have high colony-forming efficiency in vitro. The cells with CD133+/a2 31 hi AND CD44+/CD133+ phenotype possess increased colony forming efficiency and tumor initiation after in vivo injection (Wang \& Shen, 2011).

\begin{tabular}{|c|c|c|}
\hline Stem Cell Surface Markers & Human & Mice \\
\hline CD34 & + & + \\
\hline CD133 & + & + \\
\hline CD117 & + & + \\
\hline SCA1 & + & + \\
\hline CD44 & + & - \\
\hline CD24 & + & - \\
\hline CD20 & + & - \\
\hline CD105 & + & - \\
\hline CD326 (EpCAM) & + & - \\
\hline
\end{tabular}

Table 2. List of common cancer stem cell markers identified in human and mice

Xenotransplantation is a widely used functional assay in order to study tumor initiating properties of the CSCs. The CSCs from prostate cancer cell lines or primary prostate tumors have potential to generate prostate tumors in vivo. The observation of tumor generation in basal, luminal or neuroendocrinal layers shows the multilineage differentiation capacity of prostate CSCs (Lawson \& Witte, 2007; Wang \& Shen, 2011). The transplantation is performed on immune-deficient mice and every time at least 100 separated CSCs are required to produce tumors. The aim in CSCs theory is to find right cell, which is able to produce tumor itself in vivo. In other words, today our knowledge about the CSC characteristics is limited (Masters et al., 2008).

Side population analysis is the third method in order to identify and separate CSCs. During flow cytometer analysis, some cells are defined by pumping out the DNA-binding dye Hoechst 33342 and form a minor side population. For prostate cancer cells, these side population cells show stem cell like properties (Miki \& Rhim, 2008).

Prostate cancer research uses mainly three types of samples as primary tumor cells, prostate cancer cell lines and animal models that present prostate tumor. The primary prostate cancer cells display the original characteristics of the tumor but we have limited access to biopsy samples and they possess limited lifespan even with specific culture techniques. Additionally, the cancer stem or progenitor cell amount is minor than other tumor or possibly contaminated normal epithelial cells (Miki \& Rhim, 2008).

The permanent prostate cancer cell lines have unlimited proliferation ability, and have more cells with cancer stem cell profile, but they reflect the tumor characteristics more generally. The mouse models are also useful tools in order to understand the tumorigenic capacity of CSCs with different surface markers. In mouse the prostate CSCs express the Sca-1 (stem cell antigen-1) and the cells possessing that marker can regenerate tumors in vivo. The most important issue about mouse models is that they have unknown phenotypes different from human tumors which are not fully characterized (Miki \& Rhim, 2008).

\subsection{PCSCs in prostate cancer diagnosis and development}

The revealing of the signaling pathways and functional genes in cancer stem cells' selfrenewal and survival is important for the identification of novel therapeutic targets. 
Androgen-independent prostate cancers arise after androgen-ablation therapy for some patients. The initial idea is that minor amount of androgen-independent prostate cancer stem cells with basal cell characteristics is responsible for this transition (Kelly \& Yin, 2008). Although there are cases consisting of AR mutations or alterations in AR-signaling pathways causing the androgen-refractory prostate cancer. AR mutations may also exist in metastatic and tumorigenic cells. The selection of cells with AR mutation must include selfrenewing cells, which are metastatic cell of origin and androgen-independent but AR expressing cells. The metastatic prostate cancer should contain self-renewing cells in order to colonize in target tissue. Another alternative is that an AR expressing prostate cancer cell of origin acquires mutations causing the cell to have stem-cell properties. The progenitor cells are most likely candidates. Translocations are also common in prostate cancer originating cells and PIN (prostatic intraepithelial neoplasia). The TMPRSS2-ETS fusion gene formation after translocation cause over expression of ETS family transcription factors which are regulated by androgens (Kelly \& Yin, 2008).

\subsection{Impact of PCSCs in the treatment of prostate cancer and potential applications}

Throughout the years, the only experience obtained about prostate cancer therapy is that the prostate cancer recurs. Androgen-ablation therapy, chemotherapy, radiotherapy and even radical prostatectomy may not help to eliminate the tumor-initiating or metastatic cells. The cancer stem cell theory is a promising finding to overcome the therapy resistant tumors. The CSCs are androgen independent, replication quiescent, and therapy resistant cells and novel therapies targeting specifically to these cells is logical than targeting differentiated prostate cancer cells.

Initially the cancer was thought as a homogeneous mass of aggressively proliferative tumor cells that were targeted by cancer therapy. The cancer stem cell theory provided a novel approach to therapy since the CSCs subpopulation are distinct from other tumor cells.

Drug testing clinical trials should quantify the cancer stem cell eradication rather than total tumor decay. However, it is hard for those studies to target specifically CSCs from normal tissue specific stem cells, since both have similar expressional and antigenic profiles (Lawson \& Witte, 2007). Therefore, new markers needed to differentiate CSCs from tissue specific stem cells. MicroRNAs might be considered as novel molecules in this respect.

\section{MicroRNAs and prostate cancer}

MicroRNAs (miRNAs) are short (18-25nt) non-coding RNAs regulating gene expression during translation. They specifically target mRNAs and cause inhibition of translation, degradation of transcript or de-adenylation of poly(A) tail. In recent years miRNAs were discovered in viruses, plants and animal cells and total of 16772 miRNA have been identified 1424 of them belonging to homo sapiens (miRBase:Release17.0: April 2011) (Griffiths-Jones, 2004; Griffiths-Jones et al., 2006; Griffiths-Jones et al., 2008).

The microRNAs incompletely hybridize on target mRNAs and attract RNA Induced Silencing Complex (RISC) proteins in order to inhibit the protein synthesis. The miRNAs mostly on 5-Untranslated region of mRNA transcripts but hybridization on coding and 3UTR sequences were shown. The incomplete hybridization of miRNA occurs by a certain motif as the first 7-8 nts called seed match hybridize totally and a loop with variable hybridization pattern follow. This motif has been analyzed via verified mRNA-miRNA matches and novel target predictions can be performed by computer algorithms (Bartel, 2004). 
MicroRNA dysregulation has crucial outcomes on cellular mechanisms. Since one type of miRNA can target tens of different mRNA and all the miRNA-mRNA interactions have not been solved yet, the direct effect of miRNA expressional alteration is not clearly known. In tumors, there are enormous data about alteration of miRNA expression. Those alterations are originating from mutations in miRNA genes, mutation in genes of miRNA bioprocessing pathway proteins, and RISC group proteins (Sevli et al., 2010). The miRNA genes are mostly located on fragile sites of chromosomes and in prostate cancer widespread deregulation of miRNAs was shown (Ozen et al., 2008).

The miRNA profiling studies have been performed initially by microarray technology. The identified miRNAs are verified by RT-PCR analysis. The samples most suitable for profiling studies are primary tumors, prostate cell lines, and tumor xenograft models. Further functional studies in order to identify the target mRNA transcripts of miRNAs and possible therapeutic roles, transfection of miRNA genes or pre-miRNA forms are performed several techniques such as lipofection, viral-transfection, electroporation etc. (Sevli et al., 2010). Expressional alterations of the miRNA target transcripts can be observed as changes in transcript of protein level since the miRNA mechanism could inhibit the protein translation keeping the mRNA stable or the RISC complex may cut the mRNA causing it to get into degradation. Whichever pathway would take place depends on the RISC components (Kim \& Lee, 2009).

\subsection{The miRNA expression profiling in prostate cancer}

MicroRNAs are classified as tumor suppressor or oncomiRs depending on their expressional alteration or type of targeted mRNA. Tumor suppressor miRNAs target oncogenes keeping their protein products at normal levels and commonly down-regulated in tumors. OncomiRs target tumor suppressor transcripts and commonly up-regulated in tumors causing dysfunction of tumor-suppressor genes (Sevli et al., 2010).

It is thought that certain miRNAs are specifically deregulated in different cancer types; however, alteration of some miRNAs is observed in most of the tumors. Among them miR-21, miR291, and miR17-5p are significantly up-regulated in most of the solid tumors; therefore, they are called oncomiRs (Lu et al., 2008). Individual studies have shown that their over expression provides tumorigenesis and inhibition induces apoptosis or decreased rate of proliferation. On the other hand, we are not totally sure whether their expressional upregulation is sufficient for prostate cancer development alone, or not. Tumor suppressor miRNA act in the opposite way of oncomiRs. Tumor suppressor miRNAs are down-regulated in cancers and studies ectopically over-expressing those tumor suppressor miRNAs have shown the inhibition of proliferation, invasion and proliferation capacity (Sevli et al., 2010).

Expression profiling studies on prostate cancer has provided some miRNAs that are significantly up- or down-regulated and functional studies with these miRNAs have revealed the importance of miRNAs in tumor progression and pathogenesis. Hsa-miR-125b is overexpressed in clinical samples and androgen independent cell lines. Its upregulation is related with the androgen-independence and survival of the tumor. miR-125b targets the Her2 and Bak1 transcripts. Her2 protein has role in androgen independence in prostate cancer and Bak1 together with Bax protein have interaction in apoptotic signaling pathway (Sevli et al., 2010). Hsa-miR-21 is also over expressed in prostate cancer and effects tumorigenesis, invasion and metastasis by inhibiting the synthesis of proteins in those pathways. miR-21 also induces the motility of cancer cells and inhibits apoptosis (Sevli et al., 2010).

MiR-15a/16-1 cluster contains two different mature miRNA, transcribed together in primary microRNA form and processed by Drosha and Dicer RNases to get into mature form. These 
two miRNAs are down-regulated in some cancer types including prostate cancer. In order to check the direct roles of tumor suppressor miRNA in prostate cancer progression, knock-out animal models were investigated and hyperplasia together with increased cell proliferation and invasion of prostate tumor cells were observed in mice (Aqeilan, 2010). Ectopic turn-over of down-regulated tumor suppressor miRNAs by intra-cell delivery techniques provides the information about the therapeutic capacity of tumor suppressor miRNAs. Over-expression of miR-15a/16-1 has significant tumor regression capacity in vivo (Sevli et al., 2010).
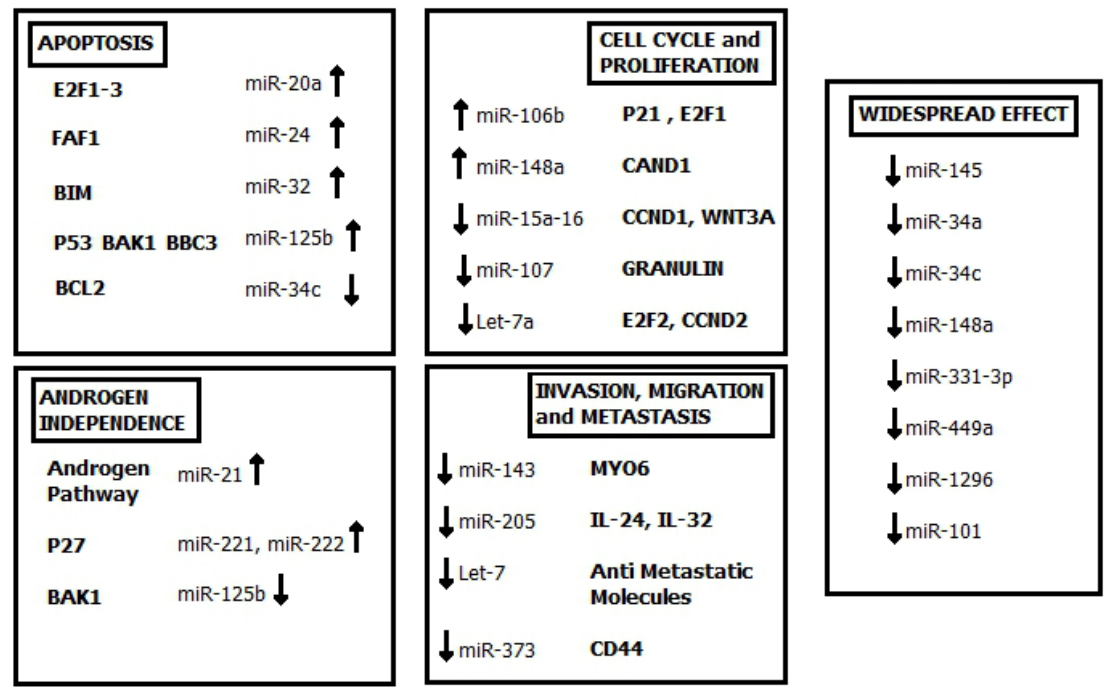

Fig. 2. A list of miRNAs with altered expression, providing their targeted messenger RNAs and pathways. Derived from (Catto et al., 2011; Sevli et al., 2010)

MiR-145 and miR143 are two of the most common deregulated tumor suppressor miRNA in all cancer types. miR-145/miR143 are also transcribed together as cluster and cleaved during maturation process. Down-regulation of miR-145 was observed prostate cancer (but not for miR143) and ectopic over-expression of miR-145 also cause anti-tumorigenic effect (our unpublished data).

Some miRNAs are reported to have functions on the androgen independency of prostate tumors. By comparing the androgen-dependent and androgen-independent prostate samples, miR-146a was revealed as taking role in androgen independency of prostate cancers.

Transcription of microRNAs is regulated by transcription factors since microRNA genes have their own promoters or they are co-regulated by the genes that host the miRNA genes in their intronic sequences. P53, a significant tumor suppressor protein is activated by the DNA-damage and induce expression of genes that carry p53 response elements on promoter sequences for promoting the repair mechanism. miR-34a, described in the last section, and miR145 are regulated by p53 protein. P53 also interacts with Drosha complex to promote the pri-microRNA to pre-microRNA conversion of miR-145's and some other microRNAs maturation (Suzuki et al., 2009).

There are some other microRNAs that are dysregulated in prostate cancer and the research findings are quite similar. The complete list of most significantly altered or mostly observed microRNAs are given in the Table-3. As the reference only one consistent article was chosen, 
but some other miRNAs that have distinct role in prostate cancer progression may be present and published.

\begin{tabular}{|c|c|c|c|}
\hline $\begin{array}{c}\text { Up- } \\
\text { regulated }\end{array}$ & Reference & $\begin{array}{c}\text { Down- } \\
\text { regulated }\end{array}$ & Reference \\
\hline Let-7 & $\begin{array}{l}\text { (Ozen et al., 2008; } \\
\text { Volinia et al., 2006), }\end{array}$ & $\operatorname{miR}-125 b$ & $\begin{array}{l}\text { (Ozen et al., 2008; } \\
\text { Schaefer et al., 2010) }\end{array}$ \\
\hline miR-182 & (Schaefer et al., 2010) & miR-15a/16-1 & (Schaefer et al., 2010) \\
\hline miR-96 & (Schaefer et al., 2010) & miR-34a & (Lodygin et al., 2008) \\
\hline \multirow[t]{7}{*}{$\operatorname{miR} 375$} & (Schaefer et al., 2010) & miR-205 & $\begin{array}{l}\text { (Schaefer et al., 2010; } \\
\text { Tang et al., 2011) }\end{array}$ \\
\hline & & miR-145 & $\begin{array}{l}\text { (Ozen et al., 2008; } \\
\text { Schaefer et al., 2010) }\end{array}$ \\
\hline & & miR-221 & $\begin{array}{l}\text { (Schaefer et al., 2010; } \\
\text { Tong et al., 2009) }\end{array}$ \\
\hline & & miR-222 & $\begin{array}{l}\text { (Schaefer et al., 2010; } \\
\text { Tong et al., 2009) }\end{array}$ \\
\hline & & miR-181b & (Schaefer et al., 2010) \\
\hline & & miR-31 & (Schaefer et al., 2010) \\
\hline & & miR-200c & (Tang et al., 2011) \\
\hline \multicolumn{4}{|c|}{ Androgen-Independence } \\
\hline $\begin{array}{l}\text { Up- } \\
\text { regulated }\end{array}$ & Reference & $\begin{array}{c}\text { Down- } \\
\text { regulated }\end{array}$ & Reference \\
\hline miR-184 & (Lin et al., 2008) & miR-128b & (Lin et al., 2008) \\
\hline miR-361 & (Lin et al., 2008) & miR-221 & (Lin et al., 2008) \\
\hline $\operatorname{miR} 424$ & (Lin et al., 2008) & miR-222 & (Lin et al., 2008) \\
\hline \multirow[t]{3}{*}{ miR-616 } & (Ma et al., 2011) & $\mathrm{miR}-146 \mathrm{a} / \mathrm{b}$ & (Lin et al., 2008) \\
\hline & & miR-148a & (Lin et al., 2008) \\
\hline & & miR-663 & (Lin et al., 2008) \\
\hline \multicolumn{4}{|c|}{ Cancer Stem Cell, Metastases, or Invasion related } \\
\hline $\begin{array}{l}\text { Up- } \\
\text { regulated }\end{array}$ & Reference & $\begin{array}{c}\text { Down- } \\
\text { regulated }\end{array}$ & Reference \\
\hline miR-377 & (Brase et al., 2011) & $\mathrm{miR}-34 \mathrm{a}$ & (Liu et al., 2011) \\
\hline \multirow[t]{4}{*}{ miR141 } & (Brase et al., 2011) & miR-143 & (Peng et al., 2011) \\
\hline & & miR-145 & (Peng et al., 2011) \\
\hline & & miR-15 & (Musumeci et al., 2011) \\
\hline & & miR-16 & (Musumeci et al., 2011) \\
\hline
\end{tabular}

Table 3. Differentially expressed miRNA implicated in prostate cancer (modified from (Sevli et al., 2010))

\section{2 miRNAs as potential targets for development of therapy in prostate cancer}

MicroRNAs have great potential as target for anti-cancer oligo-nucleotide therapy. Although their critical role in post-transcriptional gene expression is solved, more should be revealed about the specific deregulated miRNAs in individual tumors and the mRNA targets of them. Therapeutic delivery of down-regulated miRNAs is promising and lots of 
studies were performed to evaluate the potential miRNAs. The up-regulated miRNAs in prostate tumors can be inhibited by delivery of anti-miR molecules that specifically bind and form non-functional double stranded mature-miRNA molecules.

miRNA can also be used as cancer immunotherapy agents. Their immune regulatory functions were identified for certain miRNAs. miR-222 and miR-339 have role in targeting of tumors by immune cells. Some other miRNAs were identified in T-cells for immune cell regulated cancer therapy (Okada et al., 2010).

\section{PCSCs and miRNAs: Future developments of identification of new approaches for prostate cancer progression and therapy}

Some miRNAs have direct role in survival of prostate CSCs. CD44 as already known is the significant marker for CSCs in prostate tumors. The differential expression studies on CD44 positive and negative cells revealed that miR-34a is down regulated in tumors with enriched CD44 marker. Ectopic expression of miR-34a in CD44+ cells caused the decreased clonogenicity and recurrence/metastases capacity. The CD44- cells have higher miR-34a expression and down-regulation of miR-34a with antagonist antimiR molecules caused increased rate of metastasis and tumorigenesis. The CD44 transcript was found as direct target of miR-34a (Liu et al., 2011). MiR-34a is also induced by P53 tumor suppressor protein and commonly down-regulated in cancers which have decreased p53 expression. Mir-34a degrades the SIRT1, a sirtuin class III histone deacetylase protein, of which up-regulation was shown in less miR-34a expressing prostate samples.

\section{Conclusion}

Despite the recent developments on cancer diagnosis and therapy, prostate cancer still remains one of the leading cause of cancer deaths in men. New tools for precise diagnosis, distinguishing those patients who will be recurred early requiring more extensive treatments than those who will live their lifetime without not much getting affected by the disease are needed. Unlike some other types of tumors, prostate cancer is one of the tumor types in which limited treatment options are available; therefore, there is a need for novel therapy tools as well. In this chapter, two highly attracted topics, cancer stem cells and microRNAs are summarized as their role and implications in human prostate cancer arise. We believe this chapter will help to those who are interested in cancer stem cells and microRNAs not only in prostate cancer but in other applicable diseases as well.

\section{Acknowledgement}

Some of the research presented in this chapter is supported by a grant (1085051) from The Scientific and Technological Research Council of Turkey (TUBITAK).

\section{References}

Aqeilan, R.I., Calin, G.A., \& Groce, C.M. (2010). miR-15a and miR-16-1 in cancer: discovery, function and future perspectives. Cell Death and Differentiation, Vol.17, No.2, (February, 2010), pp. 215-220, 
Bartel, D.P. (2004). MicroRNAs: genomics, biogenesis, mechanism, and function. Cell, Vol.116, No.2, (2007), pp. 281-297,

Brase, J.C., Johannes, M., Schlomm, T., Fälth, M., Haese, A., Steuber, T., Beissbarth, T., Kuner, R., \& Sültmann, H. (2011). Circulating miRNAs are correlated with tumor progression in prostate cancer. International Journal of Cancer, Vol.128, No.3, (February, 2011), pp. 608-616,

Catto, J.W., Alcaraz, A., Bjartell, A.S., De Vere White, R., Evans, C.P., Fussel, S., Hamdy, F.C., Kallioniemi, O., Mengual, L., Schlomm, T., Visakorpi, T. (2011). MicroRNA in prostate, bladder, and kidney cancer: a systematic review. European Urology, Vol.59, No.5, (May, 2011), pp. 671-681

Collins, A.T. \& Maitland, N.J. (2006). Prostate Cancer Stem Cells. European Journal of Cancer, Vol.42, No.9, (June 2006), pp. 1213-1218,

Griffiths-Jones, S., Saini, H.K., van Dongen, S., \& Enright, A.J. (2008). miRBase:tools for microRNA genomics. Nucleic Acids Research, Vol.36, No.1, (2008), pp. 154-158,

Griffiths-Jones, S., Grocock, R.J., van Dongen, S., Bateman, A., \& Enright, A.J. (2006). miRBase: microRNA sequences, targets and gene nomenclature. Nucleic Acids Research, Vol.34, No.1, (2006), pp. 140-144,

Griffiths-Jones, S. (2004). The microRNA registry. Nucleic Acids Research, Vol.32, No.1, (2004), pp. 109-111,

Kelly, K. \& Yin, J.J. (2008). Prostate Cancer and Metastasis Initiating Stem Cells. Cell Research, Vol.18, No.5, (May 2008), pp. 528-537,

Kim, W.C. \& Lee, C.H. (2009). The role of mammalian ribonucleases (RNases) in cancer. Biochimica et Biophysica acta, Vol.1796, No.2, (December 2009), pp.99-113,

Korkaya, H. \& Wicha, M.S. (2007). Selective Targeting of Cancer: A New Concept in Cancer Therapeutics. Biodrugs: Clinical Immunotherapeutics, Biopharmaceyticals, and Gene Therapy, Vol.21, No.5, (2007), pp. 299-310,

Lam, J.S. \& Reiter, R.E. (2006). Stem Cells in Prostate and Prostate Cancer Development. Urologic Oncology, Vol.24, No.2, (March-April 2006), pp. 131-140,

Lawson, D.A. \& Witte, O.N. (2007). Stem Cells in Prostate Cancer Initiation and Progression. The Journal of Clinical Investigation, Vol.117, No.8, (August, 2007), pp. 2044-2050,

Lin, S.L., Chiang, A., Chang, D., Ying, S.Y. (2008). Loss of mir-146a function in hormonerefractory prostate cancer. The RNA, Vol.14, No.3, (March, 2008), pp. 417-424,

Liu, C., Kelnar, K.,Liu, B., Chen, X., Calhoun-Davis, T., Li, H., Patrawala, L., Yan, H., Jeter, C., Honorio, S., Wiggins, J.F., Bader, A.G., Fagin, R., Brown, D., \& Tang, D.G. (2011). The MicroRNA miR-34a Inhibits Prostate Cancer Stem Cells and Metastasis by Directly repressing CD44. Nature Medicine, Vol.17, No.2, (February, 2011), pp. 211-215,

Lu, Z., Liu, M., Stribinskis, V., Klinge, C.M., Ramos, K.S., Colburn, N.H., \& Li, Y. (2008). MicroRNA-21 promotes cell transformation by targeting the programmed cell death 4 gene. Oncogene, Vol.27, No.31, (July, 2008), pp. 4373-4379,

Lobo, N.A., Shimono, Y., Qian, D., \& Clarke, M.F. (2007). The Biology of the Cancer Stem Cells. Annual Review of Cell and Developmental Biology, Vol.23, No.1, (2007), pp. 675-699,

Lodygin, D., Tarasov, V., Epanchintsev, A., Berking, C., Knyazeva, T., Körner, H., Knyazev, P., Diebold, J., \& Hermeking, H. (2008). Inactivation of miR-34a by aberrant CpG methylation in multiple types of cancer. Cell Cycle, Vol.7, No.16, (August, 2008), pp. 2591-2600,

Ma, S., Chan, Y.P., Kwan, P.S., Lee, T.K., Yan, M., Tang, K.H., Ling, M.T., Vielkind, J.R., Guan, X.Y., \& Chan, K.W. (2011). MicroRNA-616 induces androgen-independent growth of prostate cancer cells by suppressing expression of tissue factor pathway inhibitor TFPI-2. Cancer Research, Vol.71, No.2, (January, 2011), pp. 583-592, 
Masters, J.R., Kane, C., Yamamoto, H., \& Ahmed, A. (2008). Prostate Cancer Stem Cell Therapy: Hype or Hope? Prostate Cancer and Prostatic Diseases, Vol.11, No.4, (December 2008), pp. 316-319,

Miki, J. \& Rhim, J.S. (2008). Prostate Cell Cultures as in vitro Models for the Study of Normal Stem Cells and Cancer Stem Cells. Prostate Cancer and Prostatic Diseases, Vol.11, No.1, (March 2008), pp. 32-39,

Mimeault, M., Hauke, R., Mehta, P.P., \& Batra, S.K. (2007). Recent Advances in Cancer Stem/Progenitor Cell Research: Therapeutic Implications for Overcoming Resistance to the Most Aggressive Cancers. Journal of Cellular and Molecular Medicine, Vol.11, No.5, (September-October, 2007), pp. 981-1011,

Musumeci, M., Coppola, V., Addario, A., Patrizii, M., Maugeri-Saccà, M., Memeo, L., Colarossi, C., Francescangeli, F., Biffoni, M., Collura, D., Giacobbe, A., D'Urso, L., Falchi, M., Venneri, M.A., Muto, G., De Maria, R., \& Bonci, D. (2011). Control of tumor and microenvironment cross-talk by miR-15a and miR-16 in prostate cancer. Oncogene, (May, 2011), Epub ahead of print,

Okada, H., Kohanbash, G., \& Lotze, M.T. (2010). MicroRNAs in Immune Regulation: Opportunities for Cancer Immunotherapy. The International Journal of Biochemistry and Cell Biology, Vol.42, No.8, (August, 2010), pp. 1256-1261,

Ozen, M., Creighton, C.J., Ozdemir, M., Ittmann, M. (2008). Widespread deregulation of microRNA expression in human prostate cancer. Oncogene, Vol.27, No.12, (March 2008), pp. 1788-1793,

Peng, X., Guo, W., Liu, T., Wang, X., Tu, X., Xiong, D., Chen, S., Lai, Y., Du, H., Chen, G., Liu, G., Tang, Y., Huang, S., \& Zou, X. (2011). Identification of miRs-143 and -145 that Is Associated with Bone Metastasis of Prostate Cancer and Involved in the Regulation of EMT. PLOS One, Vol.6, No.5, (May 2011), e20341,

Sevli, S., Uzumcu, A., Solak, M., Ittman, M., \& Ozen, M. (2010). The Function of MiRNAs, the Small but Potent Molecules, in Human Prostate Cancer. The Prostate Cancer and Prostatic Diseases, Vol.13, No.3, (September 2010), pp. 208-217,

Schaefer, A., Jung, M., Mollenkopf, H.J., Wagner, I., Stephan, C., Jentzmik, F., Miller, K., Lein, M., Kristiansen, G., \& Jung, K. (2010). Diagnostic and prognostic implications of microRNA profiling in prostate carcinoma. International Journal of Cancer, Vol.126, No.5, (March, 2010), pp. 1166-1176,

Suzuki, H.I., Yamagata, K., Sugimoto, K., Iwamoto, T., Kato, S., \& Miyazono, K. (2009). Modulation of microRNA processing by p53. Nature, Vol.460, No.7254, (July, 2009), pp. 529-533,

Tang, X., Tang, X., Gal, J., Kyprianou, N., Zhu, H., \& Tang, G. (2011). Detection of microRNAs in prostate cancer cells by microRNA array. Methods in Molecular Biology, Vol.732, No.1, (2011), pp. 69-88,

Tong, A.W., Fulgham, P., Jay, C., Chen, P., Khalil, I., Liu, S., Senzer, N., Eklund, A.C., Han, J., \& Nemunaitis, J. (2009). MicroRNA profile analysis of human prostate cancers. Cancer Gene Therapy, Vol.16, No.3, (March, 2009), pp.206-216,

Wang, Z.A. \& Shen, M.M. (2011). Revisiting the Concept of Cancer Stem Cells in Prostate Cancer. Oncogene, Vol.30, No.11, (March, 2011), pp. 1261-1271,

Volinia, S., Calin, G.A., Liu, C.G., Ambs, S., Cimmino, A., Petrocca, F., Visone, R., Iorio, M., Roldo, C., Ferracin, M., Prueitt, R.L., Yanaihara, N., Lanza, G., Scarpa, A., Vecchione, A., Negrini, M., Harris, C.C., Croce, C.M. (2006). A microRNA expression signature of human solid tumors defines cancer gene targets. Proceedings of the National Academy of Sciences of the United States of America, Vol.103, No.7, (February, 2006), pp. 2257-2261, 


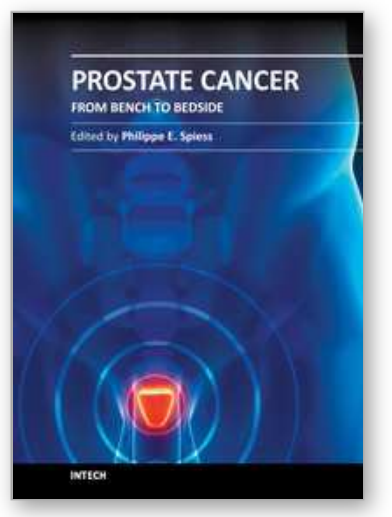

\section{Prostate Cancer - From Bench to Bedside}

Edited by Dr. Philippe E. Spiess

ISBN 978-953-307-331-6

Hard cover, 528 pages

Publisher InTech

Published online 25, November, 2011

Published in print edition November, 2011

The present textbook highlights many of the exciting discoveries made in the diagnosis and treatment of prostate cancer over the past decade. International thought leaders have contributed to this effort providing a comprehensive and state-of-the art review of the signaling pathways and genetic alterations essential in prostate cancer. This work provides an essential resource for healthcare professionals and scientists dedicated to this field. This textbook is dedicated to the efforts and advances made by our scientific community, realizing we have much to learn in striving to some day in the not too distant future cure this disease particularly among those with an aggressive tumor biology.

\section{How to reference}

In order to correctly reference this scholarly work, feel free to copy and paste the following:

Mustafa Ozen and Serhat Sevli (2011). The Role of Cancer Stem Cells and MicroRNAs in Human Prostate Cancer, Prostate Cancer - From Bench to Bedside, Dr. Philippe E. Spiess (Ed.), ISBN: 978-953-307-331-6, InTech, Available from: http://www.intechopen.com/books/prostate-cancer-from-bench-to-bedside/the-role-ofcancer-stem-cells-and-micrornas-in-human-prostate-cancer

\section{INTECH}

open science | open minds

\section{InTech Europe}

University Campus STeP Ri

Slavka Krautzeka 83/A

51000 Rijeka, Croatia

Phone: +385 (51) 770447

Fax: +385 (51) 686166

www.intechopen.com

\section{InTech China}

Unit 405, Office Block, Hotel Equatorial Shanghai

No.65, Yan An Road (West), Shanghai, 200040, China

中国上海市延安西路65号上海国际贵都大饭店办公楼405单元

Phone: +86-21-62489820

Fax: +86-21-62489821 
(C) 2011 The Author(s). Licensee IntechOpen. This is an open access article distributed under the terms of the Creative Commons Attribution 3.0 License, which permits unrestricted use, distribution, and reproduction in any medium, provided the original work is properly cited. 